\title{
Impact of Hepatitis C Viral Load in Chronic Kidney Disease Patients
}

\author{
Walid Ahmed Ragab Abdelhamid ${ }^{1}$, Alsayed Alnahal ${ }^{1}$, Ayman Zaki ${ }^{2}$, \\ Ayman Fathy Elsayed ${ }^{1}$ \\ ${ }^{1}$ Department of Internal Medicine, Faculty of Human Medicine, Zagazig University, \\ Zagazig, Egypt. \\ ${ }^{2}$ Department of Gastroenterology, Alahrar teaching hospital, Zagazig, Egypt.
}

Corresponding Author Walid Ahmed Ragab Abdelhamid

Mobile:

00201062904443

E mail:

WAAbdelHamid@medi cine.zu.edu.eg

Key words:

Bilirubin, Chronic Hepatitis C, Chronic kidney diseases, Glomerular Filtration Rate, Viral Load
Background and study aims: Chronic hepatitis $\mathrm{C}$ virus (HCV) infection is linked to chronic kidney disease (CKD) and hastens its progress to end-stage renal disease (ESRD). Previous studies have examined the association between chronic $\mathrm{HCV}$ and $\mathrm{CKD}$ and reported that $\mathrm{HCV}$ is correlated with proteinuria but not with low estimated glomerular filtration rate (eGFR) depending mainly on anti-HCV antibodies to diagnose chronic $\mathrm{HCV}$ infection. However, it is the $\mathrm{HCV}$ viral load to diagnose active HCV infection. Therefore, our study aimed to elucidate the relationship between $\mathrm{HCV}$ viral load and CKD.

Patients/Material and Method: It's a cross-sectional observational study that included 204 subjects that were classified into group 1 (90 chronic $\mathrm{HCV}$ patients without a history of chronic kidney disease) and group 2 (114 chronic HCV patients with a history of chronic kidney disease). All subjects underwent full history taking, medical examination, and laboratory investigation from May 2017 to May 2019.

Results: In CKD patients, HCV viral load was correlated with age, platelet count, serum creatinine, eGFR, and serum bilirubin. Higher HCV viral load was one of the significant predictors of low eGFR in patients with chronic $\mathrm{HCV}$ infection in addition to the female sex, older age, lower hemoglobin, higher international normalized ratio, and higher alanine transaminase.

Conclusion: There is a strong positive association between HCV viral load and serum creatinine in CKD patients. Higher $\mathrm{HCV}$ viral load carries a greater risk for lower eGFR in patients with chronic HCV infection .

\section{INTRODUCTION}

Over 170 million people are chronic infected by hepatitis $\mathrm{C}$ virus (HCV) and about 3 to 4 million individuals are newly infected every year [1]. Hepatic manifestations are the most common among HCV patients. However, $40 \%$ to $74 \%$ of patients have extrahepatic manifestations, especially glomerulonephropathy [2]. Chronic HCV infection is linked to chronic kidney disease (CKD) and hastens its progress to end-stage renal disease (ESRD) [3]. Furthermore, $\mathrm{HCV}$ infection augments complications in dialysis patients and kidney transplant recipients [4]. Several researchers have studied the association between chronic HCV and CKD and disclosed that $\mathrm{HCV}$ is correlated with proteinuria but not with a low estimated glomerular filtration rate (eGFR) [5]. However, previous researchers mainly used anti$\mathrm{HCV}$ antibodies to diagnose chronic $\mathrm{HCV}$ infection. Nevertheless, it is the $\mathrm{HCV}$ viral load to diagnose active HCV infection [6]. Our study aimed to elucidate the relationship between $\mathrm{HCV}$ viral load and CKD and determine predictors of low eGFR in chronic HCV patients.

\section{PATIENTS/MATERIAL AND METHODS}

This was a cross-sectional observational study from May 2017 to May 2019. 
We included patients with a history of chronic $\mathrm{HCV}$ infection after taking their informed written consent to participate in the study. Exclusion criteria were uncontrolled hypertension, active infection, ischemic heart disease, cerebrovascular stroke, inflammatory disorders, malignancy, thyroid disorders, and pregnant patients.

The subjects were categorized into:

- Group 1: It included 90 chronic HCV patients without a history of chronic kidney disease. They were 39 males and 51 females, and their ages ranged from 19 to 76 years with a mean \pm SD of $40.2 \pm 16.04$ years.

- Group 2: It included 114 chronic HCV patients with a history of chronic kidney disease. They were 65 males and 49 females, and their ages ranged from 20 to 82 years with a mean \pm SD of $55.68 \pm 13.75$ years.

Throughout the follow-up period from May 2017 to May 2019, all research participants were subjected to the following:

- A comprehensive history was obtained with stress on age, sex, drug history, and the prevalence of other medical disorders, especially diabetes, hypertension, and chronic kidney disease.

- Clinical examination included vital signs, weight, height, and features of jaundice, pallor, or bleeding tendency.

- Laboratory investigations

a) Routine investigation: Blood samples were collected after overnight fasting for 8-12 hours. After skin sterilization with the ethyl alcohol swap, $10 \mathrm{ml}$ of peripheral venous blood was withdrawn from each patient. Investigations included complete blood count (CBC), serum total bilirubin, aspartate transaminase (AST), alanine transaminase (ALT), serum albumin, total plasma protein, alpha-fetoprotein, blood urea, serum creatinine, fasting blood sugar (FBS), serum uric acid, prothrombin time, partial thromboplastin time, international normalized ratio (INR), and estimated glomerular filtration rate (eGFR), which determined using the modification of diet in renal disease $\left(\right.$ MDRD) formula: $186 \times(\text { Creatinine } / 88.4)^{-}$ ${ }^{1.154} \times(\text { Age })^{-0.203} \times(0.742$ if female $) \times(1.210$ if black).

b) Special investigation: HCV RNA PCR viral load test. Quantitative HCV RNA was measured using Amplicor 2.0 (Roche Diagnostics, Meylan, France).

Data processing was carried out using version 26 of the SPSS (Statistical Package for Social Sciences) program. We described quantitative variables using means and standard deviations and categorical variables by absolute frequencies. To check hypotheses for use in parametric experiments, the KolmogorovSmirnov and Levene tests were used. The independent sample Student's t-test was used to compare two groups of normally distributed data while Mann Whitney $U$ test was used for nonnormally distributed data. To calculate the association between two continuous variables, the Spearman correlation coefficient was used. The level of statistical significance has been determined at 5\% (P < 0.05). A highly significant difference was present if $p \leq 0.001$. Independent predictors for eGFR were determined using logistic regression analysis. All variables found significant on univariate logistic regression with a $\mathrm{p}<0.05$ were studied for multiple regression analysis.

\section{RESULTS}

The study included 204 subjects that were classified into three groups. They were matched regarding sex as shown in table 1. Other demographic characteristics varied significantly among the studied groups and group 2 had significantly older age, higher risk of hypertension (HTN) and diabetes mellitus (DM) than group 1 as presented in table 1 . In addition, we encountered significant differences between the studied groups regarding laboratory data and group 2 had significantly lower hemoglobin, higher INR, higher ALT, lower serum albumin, higher serum creatinine, lower eGFR and higher $\mathrm{HCV}$ viral load than group 1 as presented in table 2. Additionally, we found that in group 1 high HCV viral load (> $800000 \mathrm{IU} / \mathrm{mL}$ ) was strongly positively correlated with the female sex, weight, BMI, while it was negatively correlated with serum albumin, and serum bilirubin. In group 2, we found that high HCV viral load (> $800000 \mathrm{IU} / \mathrm{mL}$ ) load was positively correlated with age, platelet count, serum creatinine, while it was negatively correlated with eGFR, and serum bilirubin as shown in table 3.

Female sex, older age, hemoglobin, INR, HCV viral load (> $800000 \mathrm{IU} / \mathrm{mL})$, ALT, and serum 
albumin represented the significant predictors of low eGFR in chronic HCV patients on univariate analysis of all risk factors in our patients' groups as shown in table 4. Finally, after fixing of all non-significant risk factors on multivariate analysis, we found that HCV viral load (> 800 $000 \mathrm{IU} / \mathrm{mL}$ ) is one of the significant predictors of low eGFR in chronic HCV patients $(\mathrm{P}=0.003)$ as shown in table 5 .

Table (1): Comparison of the studied groups regarding demographic data.

\begin{tabular}{|c|c|c|c|}
\hline Variable & Group 1 & Group 2 & p-value \\
\hline Age (years) & $40.2 \pm 16$ & $55.68 \pm 13.7$ & $<0.001 * *$ \\
\hline \multicolumn{4}{|l|}{ Sex } \\
\hline Male & $39(43.3)$ & $65(57)$ & 0.053 \\
\hline Female & $51(56.7)$ & $49(43)$ & \\
\hline Weight (kg) & $73 \pm 12.55$ & $76.9 \pm 15.7$ & 0.073 \\
\hline BMI $\left(\mathrm{kg} / \mathrm{m}^{2}\right)$ & $27.3 \pm 4.9$ & $28.5 \pm 5.98$ & 0.148 \\
\hline HTN & $0(0)$ & $13(11.4)$ & $<0.001 * *$ \\
\hline $\mathrm{DM}$ & $0(0)$ & $25(21.9)$ & $<0.001 * *$ \\
\hline
\end{tabular}

Data are presented as number $(\%)$ or mean \pm standard deviation, (**): Highly significant, (BMI): Body mass index, (HTN): Hypertension, (DM): Diabetes mellitus.

Table (2): Comparison of the studied groups regarding laboratory data.

\begin{tabular}{|c|c|c|c|}
\hline Variable & Group 1 & Group 2 & p-value \\
\hline Hemoglobin $(\mathrm{g} / \mathrm{dL}):$ Mean $\pm S D$ & $13.09 \pm 1.84$ & $11.88 \pm 1.65$ & $<0.001 * *$ \\
\hline $\mathrm{WBC}\left(\mathrm{x} 10^{3} / \mathrm{mm}^{3}\right):$ Mean $\pm S D$ & $7.4 \pm 1.8$ & $7.34 \pm 1.97$ & 0.728 \\
\hline Platelets $\left(\mathrm{x} 10^{3} / \mathrm{mm}^{3}\right):$ Median (Range) & $213.5(102-344)$ & $205.5(79-819)$ & 0.055 \\
\hline INR: Mean $\pm S D$ & $1.03 \pm 0.063$ & $1.1 \pm 0.14$ & $<0.001 * *$ \\
\hline Bilirubin (mg/dL): Mean $\pm S D$ & $0.7 \pm 0.34$ & $0.73 \pm 0.29$ & 0.126 \\
\hline ALT (U/L): Median (Range) & $27(16-68)$ & $31(10-234)$ & $0.012 *$ \\
\hline Albumin (g/dL): Mean $\pm S D$ & $4.3 \pm 0.38$ & $4.09 \pm 0.47$ & $<0.001 * *$ \\
\hline Creatinine (mg/dL): Median (Range) & $0.6(0.4-0.8)$ & $2.96(0.7-13)$ & $<0.001 * *$ \\
\hline $\begin{array}{l}\text { eGFR }\left(\mathrm{ml} / \mathrm{min} / 1.73 \mathrm{~m}^{2}\right) \text { : Median } \\
\text { (Range) }\end{array}$ & $\begin{array}{c}135.5 \\
(101.2-272.2)\end{array}$ & $\begin{array}{c}19.55 \\
(4.3-91.2)\end{array}$ & $<0.001 * *$ \\
\hline $\begin{array}{l}\text { HCV PCR (IU/mL): Median } \\
\text { (Range) }\end{array}$ & $\begin{array}{c}179374 \\
(2200-3020977)\end{array}$ & $\begin{array}{c}520000 \\
(3320-9571000)\end{array}$ & $<0.001 * *$ \\
\hline
\end{tabular}

(Sig): Significance, $(* *)$ : Highly significant, (WBC): White blood cells, (INR): International normalized ratio, (ALT): Alanine transaminase, (eGFR): Estimated glomerular filtration rate.

Table (3): Correlation between HCV viral load and selected study parameters in groups 1 and 2.

\begin{tabular}{|c|c|c|c|c|}
\hline \multirow{2}{*}{ Variables } & \multicolumn{2}{|c|}{ Group 1 } & \multicolumn{2}{c|}{ Group 2 } \\
\cline { 2 - 5 } & $\mathrm{r}$ & $\mathrm{p}$-value & $\mathrm{r}$ & $\mathrm{p}$-value \\
\hline Female sex & +0.284 & $0.007^{* *}$ & -0.131 & 0.166 \\
\hline HTN & - & - & +0.089 & 0.347 \\
\hline DM & - & - & -0.015 & 0.870 \\
\hline Age & +0.108 & 0.311 & +0.251 & $0.007^{* *}$ \\
\hline Weight & +0.281 & $0.007^{* *}$ & +0.156 & 0.097 \\
\hline BMI & +0.417 & $<0.001^{* *}$ & +0.105 & 0.267 \\
\hline Hemoglobin & +0.075 & 0.485 & +0.092 & 0.328 \\
\hline WBC & -0.016 & 0.877 & +0.107 & 0.256 \\
\hline Platelets & -0.006 & 0.954 & +0.188 & $0.045^{*}$ \\
\hline INR & -0.122 & 0.253 & +0.003 & 0.978 \\
\hline eGFR & -0.110 & 0.301 & -0.222 & $0.018^{*}$ \\
\hline Bilirubin & -0.214 & $0.042^{*}$ & -0.271 & $0.004^{* *}$ \\
\hline Creatinine & +0.107 & 0.314 & +0.231 & $0.013^{*}$ \\
\hline ALT & +0.139 & 0.191 & -0.034 & 0.718 \\
\hline Albumin & -0.224 & $0.034^{*}$ & +0.068 & 0.469 \\
\hline
\end{tabular}


(r): Spearman's rank correlation coefficient, (*): Significant, (**): Highly significant, (HTN): Hypertension, (DM): Diabetes mellitus, (BMI): Body mass index, (WBC): White blood cells, (INR): International normalized ratio, (ALT): Alanine transaminase, and (eGFR): Estimated glomerular filtration rate.

Table (4): Univariate logistic regression of low eGFR $\left(<60 \mathrm{ml} / \mathrm{min} / 1.73 \mathrm{~m}^{2}\right)$ in groups 1 and 2.

\begin{tabular}{|l|c|c|c|c|c|}
\hline \multicolumn{1}{|c|}{ Variables } & $\beta$ & SE & OR & 95\% CI & p-value \\
\hline Female sex & +0.716 & 0.285 & 2.045 & $(1.171-3.574)$ & $0.012^{*}$ \\
\hline Age & +0.055 & 0.010 & 1.057 & $(1.036-1.078)$ & $<0.001^{* *}$ \\
\hline Weight & +0.012 & 0.010 & 1.012 & $(0.992-1.031)$ & 0.235 \\
\hline BMI & +0.009 & 0.025 & 1.009 & $(0.960-1.060)$ & 0.716 \\
\hline Hemoglobin & -0.411 & 0.090 & 0.663 & $(0.556-0.791)$ & $<0.001^{* *}$ \\
\hline WBC & +0.000 & 0.074 & 1.000 & $(0.865-1.156)$ & 0.997 \\
\hline Platelets & -0.001 & 0.002 & 0.999 & $(0.995-1.002)$ & 0.512 \\
\hline INR & +4.293 & 1.428 & 73.161 & $(4.457-1200)$ & $0.003^{* *}$ \\
\hline HCV PCR & +0.544 & 0.167 & 1.723 & $(1.242-2.390)$ & $0.001^{* *}$ \\
\hline Bilirubin & +0.197 & 0.453 & 1.217 & $(0.501-2.960)$ & 0.664 \\
\hline ALT & +0.027 & 0.009 & 1.027 & $(1.009-1.047)$ & $0.004^{* *}$ \\
\hline Albumin & -0.797 & 0.331 & 0.450 & $(0.236-0.861)$ & $0.016^{*}$ \\
\hline
\end{tabular}

$(\beta)$ : regression Coefficient, (SE): standard error, (OR): Odds Ratio, (95\%CI): 95\% confidence interval, $(*)$ : Significant, $(* *)$ : Highly significant, (BMI): Body mass index, (WBC): White blood cells, (INR): International normalized ratio, (ALT): Alanine transaminase, and (eGFR): Estimated glomerular filtration rate.

Table (5): Multivariate logistic regression of low eGFR $\left(<60 \mathrm{ml} / \mathrm{min} / 1.73 \mathrm{~m}^{2}\right)$ in groups 1 and 2.

\begin{tabular}{|c|c|c|c|c|c|}
\hline Variables & $\beta$ & SE & OR & $95 \%$ CI & $\mathrm{p}$-value \\
\hline Female sex & +0.749 & 0.372 & 2.115 & $(1.021-4.381)$ & $0.044^{*}$ \\
\hline Age & +0.048 & 0.012 & 1.049 & $(1.025-1.074)$ & $<0.001^{* *}$ \\
\hline Hemoglobin & -0.529 & 0.116 & 0.589 & $(0.470-0.739)$ & $<0.001^{* *}$ \\
\hline INR & +4.640 & 1.713 & 103.514 & $(3.604-2973)$ & $0.007^{* *}$ \\
\hline HCV PCR & +0.624 & 0.209 & 1.866 & $(1.238-2.813)$ & $0.003^{* *}$ \\
\hline ALT & +0.028 & 0.011 & 1.028 & $(1.006-1.051)$ & $0.014^{*}$ \\
\hline Albumin & +0.136 & 0.404 & 1.145 & $(0.519-2.528)$ & 0.737 \\
\hline
\end{tabular}

$(\beta)$ : regression Coefficient, (SE): standard error, (OR): Odds Ratio, $(95 \% \mathrm{CI})$ : $95 \%$ confidence $(*)$ : Significant, (**): Highly significant, (INR): International normalized ratio, and (ALT): Alanine transaminase.

\section{DISCUSSION}

A known cause for the progression of CKD to ESRD is HCV infection, which is followed by shorter survival in CKD patients [2]. Additionally, the frequency of HCV infection is higher among CKD patients than in the general population, and it is principally higher in hemodialysis patients [7]. Furthermore, HCV infection augments complications in dialysis patients and kidney transplant recipients [4].

Our study included 204 subjects that were classified into group 1 ( 90 chronic HCV patients without a history of chronic kidney disease) and group 2 (114 chronic HCV patients with a history of chronic kidney disease).

Regarding the comparison of the demographic data of the studied groups, group 2 had a significantly older age than group 1 because the elderly are exposed to cardiovascular risk factors, high blood pressure, and diabetes for life, and these diseases may also damage the kidneys [8]. Group 2 also had a higher risk of hypertension (HTN) and diabetes mellitus (DM) than group 1, since these conditions are wellknown risk factors for kidney disease initiation and progression [9].

Regarding the comparison of the laboratory data of the studied groups, group 2 had significantly lower hemoglobin than group 1. That result against that obtained by Tsai et al [10]. It can be due to relative erythropoietin insufficiency, elevated hepcidin levels, reduced erythrocyte lifespan, and disturbed iron metabolism [11]. INR was significantly higher in group 2 than in group 1 because CKD affects clotting function and causes bleeding tendency [12]. In addition, group 1 and had higher ALT and lower albumin than group 2 due to chronic necroinflammatory damage of liver cells by HCV [13]. These results agree with Afify et al. [13] and Fujita et al. [14]. Finally, group 2 had a significantly higher HCV viral load than group 1 , which may be because 
the higher HCV viral load can cause more significant glomerulopathy. Additionally, CKD patients are immunocompromised, which raises the risk of infection [15].

Our study showed that HCV viral load in group 1 was strongly correlated with female sex, weight, BMI, serum albumin, and serum bilirubin. In group 2, HCV viral load was strongly correlated with age, platelet count, eGFR, serum creatinine, and serum bilirubin. In CKD patients, the strong association between HCV viral load and old age can be explained by that elderly have higher exposure to oxidative stress, lower hepatic blood flow, diminished mitochondrial function, and weakened immunity [16]. Additionally, the platelet count was strongly positively associated with HCV viral load in CKD patients, as a higher platelet count may suggest malnutrition inflammation cachexia syndrome (MICS) with an abnormal immune response in CKD [17]. Moreover, the strong negative correlation between HCV viral load and serum bilirubin in CKD patients may be explained by that the lower serum bilirubin loses its protective antiinflammatory effects in CKD patients, causing further renal damage and resulting in higher HCV viral load [18]. Additionally, HCV viral load was strongly correlated with eGFR and serum creatinine in CKD patients and these results agreed with Kim et al [19]. Finally, we noticed that the HCV viral load in CKD patients did not affect the liver condition, but negatively affected the renal condition.

The negative association between $\mathrm{HCV}$ viral load and serum creatinine may be either a sequence of immunocompromised state in CKD or a causal relationship as $\mathrm{HCV}$ infection can result in glomerular damage by causing extrahepatic manifestations including membranoproliferative glomerulonephritis, cryoglobulinemia, focal segmental glomerulosclerosis, renal thrombotic microangiopathy, and membranous nephropathy [20].

Our results showed that the probability of low eGFR $\left(<60 \mathrm{ml} / \mathrm{min} / 1.73 \mathrm{~m}^{2}\right)$ in groups 1 and 2 by univariate binary logistic regression was significantly greater with female sex [odds ratio (OR): $2.045,95 \%$ confidence interval (CI): 1.071- 3.574 and $\mathrm{P}=0.012$ ], older age [OR: $1.057,95 \% \mathrm{CI}: 1.036-1.078$ and $\mathrm{P}=<0.001]$, lower hemoglobin [OR: $0.090,95 \%$ CI: 0.5560.791 and $\mathrm{P}=<0.001$ ], higher INR [OR: 73.1, 95\% CI: 4.457-1200 and $\mathrm{P}=0.003$ ] higher $\mathrm{HCV}$ viral load (> $800000 \mathrm{IU} / \mathrm{mL}$ ) [OR: $1.723,95 \%$ CI: 1.242-2.390, P = 0.001], higher serum ALT [OR: $1.027,95 \%$ CI : 1.009-1.047, P = 0.004], and lower serum albumin [OR: $0.450,95 \% \mathrm{CI}$ : $0.236-0.861, \quad \mathrm{P}=0.016]$. Analysis of the significant predictors of low eGFR $(<60$ $\mathrm{ml} / \mathrm{min} / 1.73 \mathrm{~m}^{2}$ ) in group 1 and group 2 in our study as identified by univariate binary logistic regression was done using multivariate logistic regression after fixing all other non-significant variables. The analysis showed that the probability of low eGFR was significantly higher with female sex, older age, hemoglobin, INR, $\mathrm{HCV}$ viral load (> $800000 \mathrm{IU} / \mathrm{mL}$ ), and ALT.

The drawbacks of our research are that the study involved a comparatively limited number of patients with CKD, the status of liver fibrosis was not determined and the real time of acquisition of $\mathrm{HCV}$ infection was not assessed.

\section{CONCLUSION}

This cross-sectional study showed that HCV viral load was negatively associated with eGFR in chronic $\mathrm{HCV}$ patients. The relationship was significant, when chronically $\mathrm{HCV}$-infected patients had chronic kidney disease. Higher $\mathrm{HCV}$ viral load (> $800000 \mathrm{IU} / \mathrm{mL}$ ) represents one of the important predictors of low eGFR $(<60$ $\mathrm{ml} / \mathrm{min} / 1.73 \mathrm{~m} 2$ ) in chronic HCV patients.

\section{List of Abbreviations:}

Hepatitis C Virus (HCV), Chronic kidney disease (CKD), End-stage renal disease (ESRD), Estimated glomerular filtration rate (eGFR), Complete blood count (CBC), Aspartate transaminase (AST), Alanine transaminase (ALT), Fasting blood sugar (FBS), International normalized ratio (INR), Modification of diet in renal disease (MDRD), Statistical Package for the Social Sciences (SPSS), Hypertension (HTN), Diabetes mellitus (DM).

\section{Acknowledgment:}

We appreciate the workers employed in our hospital's outpatient clinics and the subjects of the research who without their cooperation, we would not have accomplished our study.

Ethical considerations: Approval of the institutional review board of the ethical committee was done before the study.

\section{Name of the funding agency of the study:} None. 


\section{Conflict of interest: None}

Authors' contribution: All authors contributed substantially to the conception, design of the study; collection, analysis, and interpretation of data.

\section{REFERENCES}

1. Lauer GM, Walker BD. Hepatitis C Virus Infection. N Engl J Med 2001; 345(1):41-52.

2. Perico N, Cattaneo D, Bikbov B, Remuzzi G. Hepatitis C Infection and Chronic Renal Diseases. Clin J Am Soc Nephrol 2009; 4: 207-220.

3. Park H, Chen C, Wang W, Henry L, Cook RL, Nelson DR. Chronic hepatitis C virus (HCV) increases the risk of chronic kidney disease (CKD) while effective $\mathrm{HCV}$ treatment decreases the incidence of CKD. Hepatology 2017; 67: 492-504.

4. Scott DR, Wong JKW, Spicer TS, Dent H, Mensah FK, McDonald S, et al. Adverse Impact of Hepatitis C Virus Infection on Renal Replacement Therapy and Renal Transplant Patients in Australia and New Zealand. Transplantation 2010; 90: 1165-1171.

5. Fabrizi F, Martin P, Dixit V, Messa P. Hepatitis C Virus Infection and Kidney Disease: A MetaAnalysis. Clin J Am Soc Nephrol 2012; 7: 549-57.

6. Lai TS, Lee MH, Yang HI, You SL, Lu SN, Wang LY, et al. High hepatitis C viral load and genotype 2 are strong predictors of chronic kidney disease. Kidney Int 2017; 92: 703-709.

7. Goodkin DA, Bieber B, Jadoul M, Martin P, Kanda E, Pisoni RL. Mortality, Hospitalization, and Quality of Life among Patients with Hepatitis C Infection on Hemodialysis. Clin J Am Soc Nephrol 2016; 12: 287-297.

8. Muntner P. Longitudinal Measurements of Renal Function. Semin Nephrol 2009; 29: 650-657.

9. Kazancioğlu R. Risk factors for chronic kidney disease: an update. Kidney Int Suppl 2013; 3: 368371.
10. Tsai MH, Lin KH, Lin KT, Hung CM, Cheng HS, Tyan YC, et al. Predictors for Early Identification of Hepatitis C Virus Infection. Biomed Res Int $2015 ; 2015$.

11. Babitt JL, Lin HY. Mechanisms of Anemia in CKD. J Am Soc Nephrol 30; 23: 1631-1634.

12. Kumar S, Lim E, Covic A, Verhamme P, Gale CP, Camm AJ, et al. Anticoagulation in Concomitant Chronic Kidney Disease and Atrial Fibrillation. $J$ Am Coll Cardiol 2019; 74 2204-2215.

13. Afify M, Hamza AH, Alomari RA. Correlation Between Serum Cytokines, Interferons, and Liver Functions in Hepatitis C Virus Patients. $J$ Interferon Cytokine Res 2017; 37: 32-38.

14. Fujita K, Oura K, Yoneyama H, Shi T, Takuma K, Nakahara $\mathrm{M}$, et al. Albumin-bilirubin score indicates liver fibrosis staging and prognosis in patients with chronic hepatitis C. Hepatol Res 2019; 49: 731-742.

15. Fabrizi F, Messa P. The epidemiology of HCV infection in patients with advanced CKD/ESRD: A global perspective. Semin Dial 2019; 32: 93-98.

16. Reid M, Price JC, Tien PC. Hepatitis C Virus Infection in the Older Patient. Infect Dis Clin North Am 2017; 31: 827-838.

17. Forbes S, Ashman N, Yaqoob M. The role of platelets in the prognosis of renal disease. $O A$ Nephrology 2013; 1: 17.

18. Ahn KH, Kim SS, Kim WJ, Kim JH, Nam YJ, Park SB, et al. Low serum bilirubin level predicts the development of chronic kidney disease in patients with type 2 diabetes mellitus. Korean $J$ Intern Med 2017; 32: 875-882.

19. Kim SM, Song IH. Hepatitis C virus infection in chronic kidney disease: paradigm shift in management. Korean J Intern Med 2018; 33: 670678.

20. Ozkok A. Hepatitis C virus associated glomerulopathies. World J Gastroenterol 2014; 20: 7544-7554. 